Adam ROMEJKO (iD

University of Gdańsk, Faculty of Social Sciences, Poland

\title{
Cynthia L. Haven, Evolution of Desire. A Life of René Girard, East Lansing 2018, pp. 317
}

$\mathbf{M}$

ichigan State University publishes a series of books devoted to the thought of the Franco-American literary scholar and anthropologist, René Girard (1923-2015). One of the most recent among close to 40 publications in the series is authored by American journalist Cynthia L. Haven. On the 317 pages of her book, Haven undertook the presentation of Girard's biography and intellectual evolution. Haven is convinced that she is well suited to this task as she knew Girard from both the professional and the private sides. She makes a reference to that in the dedication that she placed at the beginning of the book: "For René, with all my love (but not the triangular sort)". Those acquainted with Girard's thought know what this "triangular love" is - a love marked by jealousy and competition that lead to violence - not only spiritual but also (and perhaps above all) physical. The author systematically emphasizes her friendly relations with the Girard family, including René himself, what she references once more in the last sentence of the Acknowledgements section:
"But surely my greatest thanks of all go to a man I was extremely fortunate to call my friend for eight years, René Girard, the dedicatee of this book and the maker of the feast" (p. 282). Haven also recalls a handwritten dedication which Girard placed in one of the copies of the book Mimesis and Theory: "To Cynthia, with all my thanks for her splendid contribution to my scholarly reputation" (p. 212).

The publication Evolution of Desire. A Life of René Girard is composed of fourteen chapters, namely: 1 . Introduction (pp. 1-8); 2. Magnetic North (pp. 9-26); 3. Dark Times in the City of Light (pp. 27-46); 4. Everything Is Possible (pp. 47-61); 5. Mankind Is Not so Kind (pp. 63-80); 6. The Pleasure of His Company (pp. 81-108); 7. Everything Came to Me at Once (pp. 109-120); 8. The French Invasion (pp. 121-146); 9. Le Systeme-Girard (pp. 147-174); 10. The Zero Hour of Culture (pp. 175-189); 11. Lotus Land (pp. 191-209); 12. The New Darwin of the Human Sciences (pp. 211-230); 13. Who Asks about the Souls of These Men? (pp. 231-254); 14 
Terra Incognita (pp. 255-269). The book ends with a Postscript, sub-titled Hand in Hand (pp. 271-279); followed by Acknowledgments (pp. 281-282); Chronology (pp. 283-290); Notes (pp. 291-310) and an Index of names (pp. 311-317).

Reading Evolution of Desire, one is struck by how multithreaded the narrative is. We learn not only the facts of René Girard's life, but also the main assumptions of his theory, known as - from its dominant motif, that of human imitation - mimetic theory. There are also references to the broader context of Girard's life, including to the social and political situation in France and the USA. As a side note, Haven talks about herself, wanting to emphasize in a way that she herself is also part of Girard's biography. Others met Girard through reading his books, exploring his ideas, she met him personally. She states: "...my perspective differs from most of Girard's admirers. I encountered René Girard not through theory or books, but through the man himself. Unlike many who have written about him, I came to his work through his kindness, generosity, and his personal friendship, not the other way around" (p. 6). In the last sentence of Introduction, she stresses that her book is a rare opportunity to get to know Girard's life: "We have his books; here are the outlines of the life" (p. 8).

Already in the Introduction, the author accentuates the extraordinary character of both Girard as a person and his body of work. His ideas echoed widely in the academic world - for some they were a quasi-revelation, for others an intellectual and moral scandal. The story of his life begins with a brief presentation of Avignon, the city he was born in. Centuries ago, it held true clout, above all in the Church politics. Currently, it has a provincial character, and the former splendour is visible in ruins and museums only. Girard's parents were educated; his father was a historian and served as, inter alia, custodian of the papal palace. Girard's mother, as one of the few women in the region at the time, completed her education at the matriculation level. In terms of religion, the thinker's parents were a peculiar mix - the mother was religious, while the father anti-clerical. Perhaps the fact that he was educated in Jesuit schools influenced the fact he later allowed his children to go to church and religious lessons. There was no pressure in this matter, however, and at thirteen years old René ceased to participate in Sunday services.

A difficult experience for young Girard was the move to Paris to study history. $\mathrm{He}$ did not appreciate the intellectual ossification of his professors, nor the deficits of food and fuel, which were a consequence of the war. He summed up his studies at the Paris École des Chartes (1943-1947) shortly, as "the worst experience in my life" (p. 28). Complaining of the inconveniences of living under occupation, Girard was still aware that they had little in common with the "real" war - he contrasted France with Poland in this respect: "There was no danger. France, during the occupation, was not like Poland" (p. 23). It is the first mention of Poland that appears in Evolution of Desire, others will be recounted at the end of the present review. From the perspective of later evolution of Girard's thought, the opportunity to observe the scapegoat mechanism in practice at that time was very important - he saw this in collective violence turned against those accused of collaboration with the Germans. Girard mentions that the victims were often women whose heads were shaved as punishment. Men who had joined the French resistance only right before the end of the war were 
particularly zealous persecutors, as in this way they could compensate for their own ineptitude, earlier exposed by the German invader (see pp. 35-39).

As René Girard did not want to, like his father, work as an archivist or in a similar profession, he decided to move to the USA in September 1947 and work as a teacher of French at the University of Indiana in Bloomington. Haven emphasizes that he was impatiently looking forward to his departure: "By 1947, Girard was a man who couldn't wait to throw the Middle Ages behind him" (p. 44). Girard himself thus commented his decision to travel abroad: "My first opportunity to move out was an offer to teach in the USA, and I took it immediately" (p. 45).

The stay in the USA was for René Girard an opportunity for professional and personal fulfilment. When he began the second semester of lectures, he met Martha McCullough (1929-), who signed up for his French language course. He mentions that he had problems with the correct pronunciation of her name. These problems ended when they got married on June 18,1951 , on the day of Martha's graduation. Friends remarked on her beauty and "American virtues", which in their opinion made her and René into a contrasting couple. Jean-Michel Oughourlian (1940-), in collaboration with whom Girard wrote the book Things Hidden Since the Foundation of the World, expressed the opinion that his relationship with Martha influenced his determination to stay in the US: "When you fall in love you love the place" (p. 52). A stepping stone in achieving this goal was Girard's defence of his doctoral dissertation (1950) on American Opinion on France, 1940-1943. The author points out that the dissertation revealed Girard's passion for studying what is based on mimicry, i.e. opinion. She states: "The man who would become hooked on the daily news was already glued to that mimetic phenomenon - opinion. We are mimetic creatures, and preoccupied with what others think of us" (p. 53). Haven cites Michel Serres (1930-), a friend of René Girard from Stanford University, and from 1990 a member of the French Academy, who in a speech focused on Martha delivered during the ceremony of Girard's induction into the French Academy (2005) referred to her as "steadfast, loyal, sweet, generous, modest, and reserved" (p. 55). The author of Evolution of Desire herself praises Martha as the spiritus movens of the Girard family.

Becoming a member of the French Academy was the most prestigious of the many distinctions received by René Girard. In the Chronology chapter, Haven emphasizes that in the past such greats as Voltaire, Jean Racine and Victor Hugo were inducted into the Academy. She adds that Girard was given chair number 37, previously occupied by Father Ambroise-Marie Carré (1908-2004), a Dominican order priest known for his involvement in the French resistance movement (p. 289). During his laudation, Michel Serres spoke about the importance of Girard to the intellectual world; he described him as "the Darwin of the social sciences” (p. 148).

Professional and family life posed a serious challenge. Girard had to leave the University of Indiana, what was a difficult experience - a new, younger and more promising scholar was found to take his place. This was a consequence of the fact that Girard started publishing his work relatively late, forgetting the unwritten principle of publish or perish prevalent at American universities (see p. 58). He behaved as if he were in France, where university lecturers were practically irremova- 
ble. He mentioned: "Perhaps, programmed with French attitudes, I could only imagine that a teacher, once in place, must be impossible to remove" (p. 59). This youthful misconception and oversight sent Girard onto a "peregrination" between various American universities. His last place of work (1980-1995) turned out to be Stanford University in California, where Girard retired. Climate-wise, California reminded him of the French (Provencal) homeland. One day he confided in his wife how happy he was to leave behind the long winters in Buffalo and Baltimore: "I always thought this would be the best place', he told Martha, the winters of Buffalo and Baltimore long forgotten" (p. 192).

Although the stay in the USA was associated with a need to fight for academic position, the conditions for intellectual work offered by the country allowed René Girard to achieve a lot there. Benoît Chantre (1963-), the president of a Paris association studying the mimetic theory (Association Recherches Mimétiques), with whom Girard wrote his last book Achever Clausewitz, made a reference to that when he stated: "René would never have experienced such a career in France" (p. 61). He added that the French academic world would not have supported Girard, and thus it was reasonable to compare Girard to Alexis de Tocqueville, who has also found success in America: "That is why Girard is, like Tocqueville, a great French thinker - and a great French moralist - who could yet nowhere exist but in the United States. René 'discovered America' in every sense of the word: he made the United States his second country, he made their fundamental discoveries, he is a pure 'product' of the Franco-American relationship, he finally revealed the face of a universal - and not an imperial - America” (p. 61).
Haven noted that the post-war experience of René Girard, referring to collective persecution of people accused of collaborating with the Germans, had a stimulating effect on clarification of the scapegoat concept. Sometimes it was suggested that in the south of the United States, Girard could have been an eyewitness of lynching of a black person, what Haven however considers unlikely. Girard himself recalls the animosity he encountered in Alabama for photographing blacks and whites together: "Just once in my life, I experienced such a thing as violent threat, in the days when there was still segregation in Alabama. We took a picture of blacks and whites together at a bar counter, and suddenly the people ganged up against us" (p. 79).

Apart from lectures and book publishing, Girard considered participation in scientific conferences as well as their organization an important part of his professional life. Those studying Girard's thought often invoke the symposium on literary criticism and human sciences (The Languages of Criticism and the Sciences of Man), which took place at John Hopkins University (Baltimore) on October 18-21, 1966. Cynthia Haven also discusses this conference in the chapter entitled The French Invasion - after all, René Girard was among its organizers. The European conference participants, including the then 36-year-old Jacques Derrida (1930-2004) brought with them a new model of thought, deconstructionism, which quite efficiently pushed aside the previously predominant structuralism. Girard did not identify with this intellectual novelty - in fact, he referred to it as a plague (fr. la peste, see p. 124), and it was one of the reasons for which he changed his place of work. He explained the decision as follows: "At that point, I felt at 
Johns Hopkins as alienated as in Avignon with my post-surrealistic friends. One year later deconstruction was already becoming fashionable. I felt uncomfortable with that fashion. That's the reason why I went to Buffalo in 1968" (p. 144).

In Evolution of Desire, the author points out that René Girard has influenced many people, including famous writers such as Milan Kundera (1929-) and John Maxwell Coetzee (1940-). The latter - like Girard worked at the University of Buffalo. When talking about him, Haven uses the term Girardian lens (p. 171), which is worth noting as after all the mimetic theory is not a rigid paradigm, but rather a particular type of sensitivity, a characteristic outlook on emerging problems.

A thinker influenced by René Girard - and influencing him in turn - was the Swiss Jesuit Raymund Schwager (1935-2004), professor of theology at the University of Innsbruck. Their first meeting in person took place in Sauveterre, a small town north of Avignon. Recounting this event, Haven writes about a strong breeze (p. 183) in the life of Girard, heralding an intellectual reappraisal that became apparent during his work on the book Things Hidden since the Foundation of the World. It was published in French in 1978, and nine years later in English. In France, the book was a bestseller and René Girard had become recognizable - both in the academic world and outside it. Another publishing success, as Haven mentions, was the book I see Satan fall like lightning. Schwager as an intellectual partner, but also a friend - made Girard change his critical attitude to the idea of scapegoat in the Christian space. Schwager's achievement was also to convince the Innsbruck academic community of the merit of Girard's thought. In 1988, Girard received a honoris causa doctorate at that University. Writing about the relationship between the two scholars, Haven quotes Girard, who stated that Schwager was completely free of mimetic desire and, as a result, there was no rivalry between them: "I must say on a personal level Raymund Schwager was totally alien to mimetic desire. There never was any spirit of rivalry between us, any race to the finish... He was totally selfless, the most selfless man I have encountered perhaps. The spirit of research was in him, but totally pure and totally dedicated to the truth of Christianity and to the enhancement of that truth" (pp. 226-227).

From the perspective of a reader from Poland, the mentions of this country in Evolution of Desire are of particular interest. Essentially, they relate to World War II and the Solidarity ("Solidarność") movement. Wartime cruelty is recalled, including the tragedy of Warsaw, where even nowadays one can find traces of death and violence from over seven decades ago (see pp. 32, $78,238)$. The heyday of the Solidarity movement was, according to the author (citing various opinions to support this idea), the opportunity for practical use of Girard's intuitions. However, this particular notion should be viewed as exaggerated. Haven writes that Solidarity was a nationwide social movement whose members fought for workers' rights and social change in a non-violent way. Radosław Sikorski (1963-) stressing the unexpected unification of Polish society was mentioned (pp. 277 , see 179 ) as well.

Some well-known Poles were referenced in the publication, namely: theater critic and theoretician Jan Kott (1914-2001); poet Adam Zagajewski (1945-); Pope John Paul II (1920-2005); theater director Jerzy Grotowski (1933-1999). The mention of Cardinal Jean-Marie Lustiger 
(1926-2007) was accompanied by a comment that he was born in Paris to a family of Jews coming from Poland (pp. 30, 134, 179, 277, 302).

Evolution of Desire also includes a reference to Professor Ewa Domańska (1963-), a lecturer at the University of Adam Mickiewicz in Poznań who is a guest lecturer at Stanford University every year. The author quotes her opinion on Girard's books, which were effectively in underground circulation in Poland - Domańska stated that the ideas presented therein inspired people to fight the violent institutions of the Polish state (see p. 277).

Another strength of the book written by Cynthia L. Haven are the photographs (pp. A-P) depicting René Girard, his relatives and friends. Girard is most often associated with the face of an elderly man, bony, adorned with bushy eyebrows. These photos in contrast allow one to look at him from a different perspective, that of family life, childhood memories, adolescence, etc. They come mostly from family archives. One, showing Girard smoking a cigarette outside the university club in Stanford was taken in 2006 by Ewa Domańska (p. O).

Evolution of Desire is an interesting publication. It presents the motifs from the biography of René Girard which are mostly unknown to the wider public aware of his work. It should be noted that the book will be an easy, pleasant read for a person who knows the basics of mimetic theory, but it may be more difficult for a reader just starting their adventure with Girard. For this latter group, it is recommended to reach first for other studies on Girard - luckily, there is an abundance of them available in Polish, English as well as other languages. 